\title{
Wolontariat szkolny jako narzędzie rozwoju kompetencji przedsiębiorczych
}

DOI: $10.47050 / 65591760.142-155$

Renata Rettinger

Wolontariat i inne formy działalności altruistycznej są ważnymi elementami kształtowania kluczowych kompetencji oraz uniwersalnych umiejętności niezbędnych do funkcjonowania na rynku pracy. W artykule przedstawiona zostanie działalność wolontariacka jako czynnik warunkujący kształtowanie i rozwój postaw przedsiębiorczych dzieci oraz młodzieży w szkole podstawowej. Obecnie edukacja szkolna opiera się na pewnym systemie schematów (reguł), a tym samym może ograniczać przedsiębiorczość i innowacyjność uczniów. Dlatego aktywność uczniowska w wolontariacie szkolnym może być sposobem na kształtowanie tych kompetencji.

\author{
Słowa kluczowe: \\ kompetencje \\ postawa przedsiębiorcza \\ szkoła podstawowa \\ wolontariat
}




\section{The school volunteering \\ as a tool for developing the \\ entrepreneurial competencies}

DOI: 10.47050/65591760.142-155

Renata Rettinger

In recent years, volunteering is getting more and more popular. Volunteering or other altruistic activity are an important element in shaping key competencies and universal skills necessary for functioning on the labour market. Here the closer look on volunteering in school will be taken. The main aim of the study is to analyse voluntary activities as a factor conditioning shaping and developing entrepreneurial attitudes of children and youth in primary school. Current school education is guided by a certain system of schemes (rules), and thus may limit the entrepreneurship and innovativeness of students. Therefore the activity of students in school volunteering can be the way to shape these competences.

\section{Keywords:}

competences

entrepreneurial attitude

primary school

volunteering 


\section{Wprowadzenie}

W literaturze przedmiotu istnieje wiele definicji określających, co to są przedsiębiorczość czy kompetencje przedsiębiorcze. Na potrzeby niniejszego opracowania przyjęto, że jest to zespół cech osobowości, takich jak inicjatywność, kreatywność, energia i zapał do pracy, wytrwałość w działaniu, a także ciekawość świata, pewność siebie i wiara we własne siły, samodyscyplina, skłonność do podejmowania wyważonego ryzyka i branie odpowiedzialności za siebie i innych (Rachwał 2005; Strojny 2007; Piróg 2015).

W preambule Podstawy programowej kształcenia ogólnego dla zreformowanej szkoły podstawowej zapisano: „[...] kształcenie ogólne w szkole podstawowej ma na celu: [...] rozwijanie kompetencji takich jak: kreatywność, innowacyjność i przedsiębiorczość". Chodzi tutaj bardziej o realizację tego procesu w ramach innych przedmiotów, nie zaś bezpośrednio poprzez nauczanie konkretnych treści (por. Rachwał i in. 2018). Zadaniem edukacji jest przygotowanie ludzi do adaptacji w nowych uwarunkowaniach społeczno-gospodarczych, tak aby mogli oni w sposób racjonalny wpływać na struktury, które dziś podlegają przemianom (Borowiec, Rachwał 2011). Postawy przedsiębiorcze powinny być kształtowane przez polską szkołę już od pierwszego roku edukacji wczesnoszkolnej, i to na wszystkich zajęciach, bo to warunkuje ich pełne i satysfakcjonujące uczestnictwo w życiu społeczno-gospodarczym w przyszłości (Rachwał i in. 2018; Rachwał, Wach 2016; Piróg 2015).

W kontekście edukacji i kształcenia najczęściej przytaczana jest definicja przedsiębiorczości jako zdolności osoby do wcielania pomysłów w czyn, nawiązująca do definicji przyjętej przez Komisję Europejską (Borowiec, Kilar, Rachwał 2018; Wach 2013). Obejmuje ona: twórczość, innowacyjność i podejmowanie ryzyka, a także zdolność do planowania przedsięwzięć i prowadzenia ich dla osiągnięcia zamierzonych celów. Edukacja w zakresie przedsiębiorczości odgrywa kluczową rolę w budowaniu przedsiębiorczego społeczeństwa i przedsiębiorczej gospodarki.

Wydaje się zasadne stwierdzenie, że w ramach krajowego systemu oświaty przyjęto zasadę edukacji „o" przedsiębiorczości i „dla” przedsiębiorczości, nie zaś „przez" przedsiębiorczość. Oczywiście podstawa programowa na każdym etapie kształcenia przewiduje realizację różnych przedmiotów z wykorzystaniem innowacyjnych, aktywnych metod nauczania. Zakłada też, że najlepszą metodą jest tzw. learning by doing, jednak wprowadzenie w życie takich zaleceń jest bardzo trudne (Bień- 
kowska 2017). W związku z tym należy wykorzystywać inne momenty życia szkolnego do kształcenia kompetencji, takich jak kreatywność, przedsiębiorczość i innowacyjność. Miejscem na tego typu działania może być szkolny wolontariat. Dzięki temu zostanie wykreowana możliwość nabywania takich kompetencji łącznie, na każdym etapie i niezależnie od wieku uczniów (tamże).

Jednocześnie wiele wskazuje na to, że uczniowie polskich szkół nie mają realnej możliwości rozwoju kompetencji w zakresie inicjatywności i przedsiębiorczości w ramach nauki szkolnej. Młodzi Polacy w szkole podstawowej mogą co prawda zdobyć odpowiednią wiedzę w tym zakresie, natomiast nie mają możliwości rozwoju umiejętności i odpowiednich postaw z tym związanych. Barierą rozwoju tych kompetencji są: kultura panująca w polskich szkołach, ograniczenie autonomii uczniów oraz sposób nauczania, który pomija rozwój umiejętności i postaw (Atroszko 2015). Teoretycznie uczniowie polskich szkół mogą podejmować różnorodne inicjatywy w ramach samorządu uczniowskiego. Faktycznie jednak jest to instytucja fasadowa, niemająca rzeczywistego wpływu na to, co się dzieje w szkole. Istnienie i funkcjonowanie tej instytucji można określić jako działanie pozorne (Atroszko 2015). W ostatnich latach pojawiło się wiele projektów w przestrzeni szkoły podstawowej, które mają na celu podnoszenie kompetencji uczniów w zakresie przedsiębiorczości, tworzenia pomysłów biznesowych, myślenia projektowego, kreatywności i projektowania oraz komunikacji. Jednym z takich pomysłów są spółdzielnie uczniowskie, zyskujące z każdym rokiem większą popularność wśród uczniów i nauczycieli.

Przedsiębiorczość, innowacyjność, kreatywność - to trzy pojęcia, które pojawiają się współcześnie we wszystkich dyskusjach na temat najbardziej pożądanych kompetencji na współczesnym rynku pracy oraz w kontekście najważniejszych determinant wzrostu i rozwoju gospodarczego. Kompetencje można określić jako sumę posiadanej wiedzy, umiejętności praktycznych i postaw, które przejawia dana osoba. Być przedsiębiorczym to znaczy zdobywać i rozwijać kompetencje istotne społecznie oraz korzystać z nich w sposób pozwalający na osiągnięcie sukcesu własnego lub społecznego/obywatelskiego. 


\section{Wolontariat jako forma składowa edukacji}

\section{i kształcenia w zakresie przedsiębiorczości}

Jednym z najważniejszych celów kształcenia w szkole podstawowej jest dbałość o integralny rozwój biologiczny, poznawczy, emocjonalny, społeczny i moralny ucznia. Rozwój ten powinien być realizowany nie tylko przez system obowiązkowych zajęć lekcyjnych określonych w podstawie programowej, lecz także przez inne pozalekcyjne formy aktywności szkolnej. Jedną z takich form jest szkolny wolontariat, który działa praktycznie w każdej polskiej szkole podstawowej. Jego funkcjonowanie powinno być sformalizowane i w pełni kontrolowane przez dyrekcję oraz grono pedagogiczne. Wolontariat to bezpłatne, dobrowolne, świadome działanie ucznia, studenta na rzecz innych, wykraczające poza więzi rodzinno-koleżeńsko-przyjacielskie (Górniak 2013). Wolontariat musi wynikać z motywacji człowieka do tego rodzaju aktywności.

Ustawa o pożytku publicznym i wolontariacie reguluje prawne uwarunkowania oraz klasyfikuje organizacje i instytucje prowadzące tego typu działalność, nazywając je korzystającymi:

$\rightarrow$ organizacje pozarządowe - przede wszystkim stowarzyszenia i fundacje,

$\rightarrow$ stowarzyszenia jednostek samorządu terytorialnego, np. związki gmin lub powiatów,

$\rightarrow$ osoby prawne i jednostki organizacyjne Kościoła katolickiego i innych Kościołów lub związków wyznaniowych, np. parafie, zakony,

$\rightarrow$ organy administracji publicznej - centralnej i samorządowej,

$\rightarrow$ jednostki organizacyjne podległe organom administracji publicznej lub nadzorowane przez te organy.

Rola szkoły, a w szczególności dyrekcji i grona pedagogicznego, polega na umożliwieniu podejmowania takich inicjatyw oraz wspieraniu ich działań finansowo i organizacyjnie. Pedagodzy pracujący z uczniami w ramach wolontariatu powinni stworzyć warunki sprzyjające głównej idei wolontariatu, którą jest pomaganie. Zatem rolą nauczycieli jest tworzenie atmosfery i środowiska do rozwijania kompetencji uczniowskich poprzez wachlarz inicjatyw charytatywnych. Warto też dodać, że również rodzice powinni wspierać swoje dzieci w działaniach na rzecz innych. Wsparcie nie powinno polegać na prześciganiu się w kwocie pomocy finansowej lub rzeczowej, ale na zachęcaniu do działania na 
rzecz innych. Motywy, którymi mogą kierować się wolontariusze, podejmując tego typu działania, są przede wszystkim osobiste, związane z satysfakcją z pracy (Załuska 1996). Badania wskazują, że są to: chęć pomagania innym, potrzeba serca, brak innego pożytecznego zajęcia oraz nabycie nowych umiejętności. Na podstawie dostępnej literatury przedmiotu można dokonać klasyfikacji motywów, którymi kierują się uczniowie podejmujący działania dla innych:

$\rightarrow$ poparcie określonych wartości lub idei-działania podejmowane dla zabezpieczenia potrzeb społecznie uznawanych za słuszne, np. pomoc humanitarna w sytuacjach trudnych zarówno dla ludzi, jak i zwierząt,

$\rightarrow$ chęć kreowania własnej, pozytywnej pozycji w społeczności szkolnej - działania zmierzające do stworzenia obrazu własnej osoby zgodnego z wizerunkiem powszechnie uznawanym i bardzo cenionym, czyli typem społecznika,

$\rightarrow$ chęć zaspokojenia własnych ambicji - działalność przynosząca osobie satysfakcję życiową, poczucie spełnienia oraz samorealizacji, możliwość wyrażania własnych poglądów, wcielanie w życie autorskich projektów.

Bardzo ważnym aspektem pracy jako wolontariusza jest zorientowanie na praktykę, czyli przygotowanie do wykonywania działań zmierzających do osiągnięcia celu. Nie wystarcza, by idea pomocy i współdziałania rozpowszechniała się w teorii, tu praktyczne działania muszą iść w parze z teorią, nabierając realnego kształtu (Roguska 2010). Praktyka, działanie mają tu znaczenie pierwszoplanowe, ponieważ idea pomocy innym opiera się na działaniu, jest to urzeczywistnianie zamysłów w działaniu.

Współcześnie wolontariat nie oznacza wyłącznie „zbiórki pieniędzy do puszki". Działalność wolontariacka wymaga uruchomienia pokładów kreatywności, innowacyjności i przedsiębiorczości uczniowskiej w planowaniu, organizowaniu i przeprowadzaniu imprez charytatywnych mających na celu zebranie pieniędzy lub przedmiotów. Należy podkreślić, że w działania szkolnego wolontariatu mogą włączyć się wszystkie grupy dzieci i młodzieży w szkole podstawowej - wiek może mieć jedynie wpływ na role czy pozycję w zespole. W przypadku młodszych dzieci ważną rolę odgrywa uświadomienie, że mają one szansę działać i wykazać się kompetencjami przedsiębiorczymi, że ich 
pomysły są ważne i mogą zostać zrealizowane. Zwiększanie zasięgu imprez charytatywnych wymaga od uczniów kreatywności w tworzeniu pomysłu, w jaki sposób można zebrać środki, to uruchamia postawy przedsiębiorcze.

\section{Korzyści kompetencyjne związane z działalnością $w$ wolontariacie}

Najważniejsze umiejętności, które zdobywają uczniowie w ramach tej działalności, to:

$\rightarrow$ praca z grupą i praca w zespole,

$\rightarrow$ pewność siebie,

$\rightarrow$ odwaga,

$\rightarrow$ rozwój kompetencji interpersonalnych,

$\rightarrow$ umiejętność wystąpień publicznych.

Wolontariat może więc być świadectwem człowieka z pasją, która daje mu przewagę na rynku pracy. Ideą wolontariatu jest pomaganie potrzebującym, w związku z tym kształtowanie umiejętności poprzez ten rodzaj działalności ma charakter wtórny. Rozwój młodego człowieka następuje tu przez "dawanie siebie" innym i to daje przewagę wolontariatowi nad innymi formami rozwoju (praktyki, szkolenia). Robiąc coś dla innych, wolontariusze doświadczają głębszych uczuć, co stymuluje ich kompleksowy rozwój. Wolontariat w tym rozumieniu staje się formą świadomego i aktywnego uczestnictwa w społeczeństwie obywatelskim, a wolontariusze to osoby, które podejmując decyzję o pracy charytatywnej, robią to w sposób świadomy i odpowiedzialny.

W trakcie realizacji zadań w ramach szkolnego wolontariatu uczniowie mają możliwość kształtowania tzw. kompetencji miękkich, takich jak: efektywna komunikacja, otwartość na uczenie się i rozwój, zaangażowanie, umiejętność pracy w zespole, umiejętność określania priorytetów, etyczne postępowanie, odpowiedzialność, umiejętność organizacji pracy i efektywnego zarządzania czasem oraz elastyczność i zdolność adaptacji. Można je uznać za kompetencje uniwersalne (Kulig-Moskwa 2013). Należy pamiętać, że pracodawcy chętniej angażują absolwentów aktywnych, z pasją i doświadczeniem w działalności uczniowskiej, studenckiej, społecznej i sportowej. W dalszym ciągu zauważa się brak kompetencji samoorganizacyjnych, a zatem takich cech jak: samodzielność, przedsiębiorczość, przejawianie inicjatywy, odporność na stres, 
motywacja do pracy (tamże). Wolontariat może po części wypełnić tę lukę. Rywalizacja i stawianie przed uczniami wyzwań to dobry sposób na aktywizację i nauczanie przez przedsiębiorczość oraz realizację celów użytecznych społecznie. Postawa przedsiębiorcza powinna być ważnym efektem nauki i socjalizacji w szkole.

Wolontariat pomaga młodym ludziom w byciu kreatywnym, pewnym siebie i zachowaniu się w sposób odpowiedzialny społecznie, a także pozwala na kształtowanie takich postaw wśród uczniów jak: „uczciwość, odpowiedzialność, poczucie własnej wartości, przedsiębiorczość, gotowość do podejmowania inicjatyw pracy zespołowej, postawa obywatelska". Aby zostać wolontariuszem, trzeba liczyć się z tym, że nie polega to tylko na pracy dla kogoś i pomaganiu. Osoby, które chcą zajmować się wolontariatem, muszą zdawać sobie sprawę, że będą im stawiane różne wymagania. Praca charytatywna wymaga poświęcenia. W ten sposób nasuwa się kolejny wniosek: decydując się na pracę dla innych, tych, którzy potrzebują pomocy, robimy także coś dla siebie. Nie tylko stajemy się lepszymi ludźmi, lecz także uczymy się nowych rzeczy, nabywamy nowe umiejętności i doskonalimy te już posiadane. Wolontariat $\mathrm{w}$ tym rozumieniu staje się formą świadomego i aktywnego uczestnictwa w społeczeństwie obywatelskim, a wolontariusze to osoby, które podejmując decyzję o pracy charytatywnej, robią to w sposób świadomy i odpowiedzialny. Wolontariat jest dobrowolny, a to jest bardzo ważna cecha, ponieważ w działaniach uczestniczą tylko zainteresowani uczniowie, wręcz zdeterminowani do pomocy. Taka sytuacja przyspiesza procesy edukacyjne i kształceniowe.

Działalność szkolnego wolontariatu stała się w ostatnich latach nie tylko bezinteresownym okazywaniem pomocy. Niestety, mechanizm zachęcania uczniów czy szkół do udziału w charytatywnych akcjach, opierający się na rywalizacji i nagrodach, wypaczył tę szlachetną ideę. Można sobie zadać pytanie: Czy rywalizacja uczniowskich działań w ramach wolontariatu nie przynosi oczekiwanego sukcesu w postaci coraz to większej liczby akcji, zwiększenia ich zasięgu i efektów?

\section{Szkolny wolontariat - dobre praktyki}

Szkoła podstawowa jest, wbrew pozorom, trudnym miejscem do działania wolontariatu, a wynika to z tego, że osoby małoletnie nie mogą uczestniczyć we wszystkich typach działań na rzecz innych. Ze względu na wiek uczniowie muszą być pod bezpośrednią opieką nauczycieli 
lub rodziców. Pomimo tego bardzo ważnego ograniczenia aktualnie szkoły podstawowe stały się miejscem intensywnych działań małych wolontariuszy. Z reguły placówki oświatowe nie inicjują akcji charytatywnych, ale w dużej mierze uczestniczą w akcjach o zasięgu krajowym, regionalnym i lokalnym. Oczywiście zdarzają się sytuacje, w których jest organizowana pomoc wręcz indywidualna, bardzo często dotycząca pojedynczego ucznia czy jego rodziny, ale w tym opracowaniu pod uwagę zostały wzięte duże akcje charytatywne, w które angażuje się duża liczba placówek oświatowych.

W tej części opracowania zostaną przedstawione wybrane działania społeczne realizowane w szkołach podstawowych. W większości są to działania polegające na realizacji oryginalnych projektów wolontariackich w szkołach podstawowych przez wolontariuszy rekrutujących się spośród uczniów danej szkoły. Udział w tych projektach wymaga od uczniów uruchomienia swoich kompetencji z zakresu szeroko rozumianej przedsiębiorczości i innowacyjności. Ta sytuacja wynika z olbrzymiej liczby akcji charytatywnych organizowanych przez różne instytucje i dla różnych grup docelowych. Długoletnie obserwacje działalności szkolnego wolontariatu w różnych szkołach podstawowych na terenie Krakowa mogą doprowadzić do wniosku, że następuje "zmęczenie" kolejną akcją charytatywną. Jest to pozorne stwierdzenie, ponieważ kolejne akcje pomocowe zmuszają uczniów do kreatywności i innowacyjności w zakresie zdobywania środków pomocowych. Szkoły, uczestnicząc w akcjach charytatywnych organizowanych przez Caritas Polska czy Wielką Orkiestrę Świątecznej Pomocy, organizują szkolne wydarzenia, na które składają się aukcje prac plastycznych, aukcje rzeczowe i wiele wydarzeń o charakterze kulturalnym, naukowym, sportowym, które pozwolą zebrać środki na szczytny cel.

Najczęściej w szkołach organizowane są wszelkiego rodzaju zbiórki, np. finansowe - „Góra grosza” (w 2017 r. uczestniczyło w niej 9 tys. szkół) czy Wielka Orkiestra Świątecznej Pomocy. WOŚP jest corocznym wydarzeniem, do którego szkoły przygotowują się kilka tygodni wcześniej. W 2019 r. Jerzy Owsiak zorganizował już 27. finał tego wydarzenia, w którym uczestniczyło ponad 1,5 tys. sztabów, z czego około 20 proc. to sztaby zorganizowane w szkołach podstawowych, a nawet w przedszkolach. Oprócz kwest finansowych organizowane są liczne zbiórki produktów żywnościowych, są to takie akcje jak: „Szlachetna paczka" (wartość udzielonej pomocy to około $25 \mathrm{mln}$, liczba zaanga- 
żowanych osób w pomoc to 440 tys.), „Pomóż dzieciom przetrwać zimę" (300 sztabów w Polsce) czy "Tak pomagam" organizowane przez Caritas Polska (Towarzystwo Nasz Dom 2018, Wielka Orkiestra Świątecznej Pomocy 2018, Szlachetna Paczka 2018, Ogólnopolska Akcja Charytatywna 2018, Caritas, Tak pomagam 2018).

Beneficjentami tej pomocy są różne grupy docelowe, ale w szkołach podstawowych bardzo dużym zainteresowaniem cieszy się pomoc zwierzętom. Na przykład "Gwiazdka dla zwierzaka" polega na zbiórce darów dla zwierząt mieszkających w schronisku. Placówki uczestniczące $w$ akcji otrzymują dyplomy, natomiast te, które zbiorą najwięcej darów - certyfikaty okolicznościowe. W roku szkolnym 2017/2018 w akcji uczestniczyły 242 placówki, którym udało się zebrać 20 ton karmy dla zwierząt.

Jak wielka jest rola wolontariatu, świadczy chociażby ustanowienie 5 grudnia Międzynarodowym Dniem Wolontariusza. Innym sposobem uhonorowania najmłodszych wolontariuszy są doroczne podsumowania działalności i wybór wolontariusza/wolontariuszy roku. Jest to organizowane przez szkoły, kuratoria oświaty i organizacje działające charytatywnie.

\section{Podsumowanie}

Bardzo ważnym zagadnieniem jest kontekst kształcenia i uczenia jako twórczej adaptacji do świata. Oznacza to odpowiedzialne, krytyczne i racjonalne przystosowanie się do zmieniających się uwarunkowań rozwoju współczesnego świata. Działalność w szkolnym wolontariacie pozwoli na bardzo wstępne określenie roli i pozycji młodego człowieka w społeczeństwie. Przewrotnie można powiedzieć, że młody człowiek ma możliwość zaobserwowania sytuacji, w której „można dawać", ale i "można brać". Różne aspekty związane z ekonomią społeczną - w tym wolontariat, działalność w organizacjach pozarządowych i podmiotach społecznych - z pewnością są ważnym elementem kształtowania kompetencji kluczowych i umiejętności uniwersalnych niezbędnych do funkcjonowania na rynku pracy.

Działania uczniów w szkolnym wolontariacie są bardzo dobrym przykładem edukacji przez przedsiębiorczość, gdzie nauczanie charakteryzuje się podejściem skoncentrowanym na wyzwaniach, rozwiązywaniu problemów w innowacyjny, kreatywny sposób. Dodatkowymi argumentami za wolontariatem są praktyczne działanie oraz społeczna 
użyteczność tego zjawiska. Umiejętności o charakterze ogólnym, takie jak zdolność krytycznego myślenia, podejmowanie inicjatyw, rozwiązywanie problemów i praca w grupie, przygotowują młodego człowieka na zróżnicowane i nieprzewidywalne ścieżki kariery we współczesnych czasach. Wolontariat może być przykładem aktywnej metody nauczania "o" przedsiębiorczości, "dla" przedsiębiorczości i „przez" przedsiębiorczość, realizowanych w formie projektu uczniowskiego.

Działalność w wolontariacie może spowodować, że młody człowiek będzie bardziej świadomy własnych kompetencji, talentów oraz swoich mocnych i słabych stron. To pozwoli w przyszłości kształtować swoją ścieżkę edukacyjno-zawodową poprzez poznanie samego siebie, a także poznanie możliwości stwarzanych przez współczesne procesy rozwojowe. Współcześnie wolontariat to nie tylko „zbieranie funduszy do puszki", lecz także zdobywanie doświadczenia i kompetencji, które w przyszłości będą stanowiły o potencjale młodego człowieka świadomie zarządzającego swoimi własnymi zdolnościami i talentami. Wolontariat to przede wszystkim kształtowanie aktywnej postawy społecznej i obywatelskiej. 


\section{Bibliografia}

$\rightarrow$ Atroszko, B. (2015), Rozwój kompetencji inicjatywności i przedsiębiorczości w ramach nauki szkolnej w Polsce. Reviewed Proceedings of the Interdisciplinary Scientific International Conference for PhD students and assistants QUAERE 2015, vol. V May 25-29, 2015, Hradec Králové (Ceska Republika): Magnanimitas, s. $1319-1325$.

$\rightarrow$ Bieńkowska, B. (2017), Przedsiębiorczość i innowacyjność - próba refleksji nad ich miejscem w systemie oświaty, [w:] „Research Papers of the Wroclaw University of Economics/Prace Naukowe Uniwersytetu Ekonomicznego we Wrocławiu" (489), s. 44-56.

$\rightarrow$ Borowiec, M., Rachwał, T. (2011), Kształtowanie postaw przedsiębiorczych na lekcjach geografii wyzwaniem edukacyjnym w procesach globalizacji, [w:] „Przedsiębiorczość - Edukacja", nr 7, s. 321-332.

$\rightarrow$ Borowiec-Gabryś, M., Kilar, W., Rachwał T. (2018), Przedsiębiorczość jako kompetencja przyszłości, [w:] S. Kwiatkowski (red.), Kompetencje przyszłości, Seria Naukowa, t. 3, Warszawa: Fundacja Rozwoju Systemu Edukacji, s. 68-89.

$\rightarrow$ Górniak, J. (2013), Młodość czy doświadczenie. Kapitał ludzki w Polsce. Raport podsumowujq̨cy III edycję badań BKL, 2012, s. 83-84.

$\rightarrow$ Kulig-Moskwa, K. (2013), Wolontariat jako instrument kształtowania kompetencji pożq̨danych na rynku pracy, "Zeszyty Naukowe Wyższej Szkoły Bankowej we Wrocławiu", nr 4 (36), s. 115-127.

$\rightarrow$ Piróg, D. (2015), Kompetencje z zakresu przedsiębiorczości: rozważania teoretyczne i ich ilustracje w obszarze szkolnictwa wyższego, „Przedsiębiorczość - Edukacja", nr 11, s. 364-376.

$\rightarrow$ Rachwał, T. (2005), Kształtowanie postaw u uczniów na lekcjach podstaw przedsiębiorczości, „Przedsiębiorczość - Edukacja” , nr 1, s. 137-144.

$\rightarrow$ Rachwał, T., Wach, K. (2016), Badanie intencji przedsiębiorczych młodego pokolenia: wyniki ankietyzacji wśród studentów kierunków nieekonomicznych, „Przedsiębiorczość - Edukacja”, nr 12, s. 405-415. 
$\rightarrow$ Rachwał, T., Kilar, W., Kawecki, Z., Wróbel, P. (2018), Edukacja w zakresie przedsiębiorczości w wychowaniu przedszkolnym, szkole podstawowej i szkołach średnich w świetle nowej podstawy programowej, „Przedsiębiorczość - Edukacja", nr 14, s. 389-424.

$\rightarrow$ Roguska, A. (2010), Wolontariat-działania na rzecz jednostki i społeczeństwa, [w:] M. Danielak-Chomać, B. Dobrowolska, A. Roguska (red.), Wolontariat w teorii i praktyce, Siedlce, s. 27-48.

$\rightarrow$ Strojny, J. (2007), Kształtowanie postawy przedsiębiorczej-procesy socjalizacji i autokreacji. Kształtowanie postaw przedsiębiorczych a edukacja ekonomiczna, Warszawa: Fundacja Promocji i Akredytacji Kierunków Ekonomicznych, s. 205-211.

$\rightarrow$ Wach, K. (2013), Edukacja na rzecz przedsiębiorczości wobec współczesnych wyzwań cywilizacyjno-gospodarczych, „Przedsiębiorczość - Edukacja”, nr 9, s. 246-257.

$\rightarrow$ Załuska, M. (1996), Społeczne uwarunkowania angażowania się w działalność organizacji pozarządowych, [w:] M. Załuska, J. Boczoń (red.), Organizacje pozarzq̨dowe w społeczeństwie obywatelskim, Warszawa: Interart. 


\section{Netografia}

$\rightarrow$ Towarzystwo Nasz Dom, Góra Grosza, towarzystwonaszdom.pl/app/ uploads/2017/11/Rozliczenie-Akcji-G\%C3\%B3ra-Grosza-18-edycja.pdf [dostęp 8.12.2018].

$\rightarrow$ Wielka Orkiestra Świątecznej Pomocy, www.wosp.org.pl/final/sztaby [dostęp 8.12.2018].

$\rightarrow$ Szlachetna Paczka, www.szlachetnapaczka.pl/wyniki [dostęp 13.12.2018].

$\rightarrow$ Ogólnopolska Akcja Charytatywna, Pomóż dzieciom przetrwać zimę, www.pdpz.pl [dostęp 8.12.2018].

$\rightarrow$ Caritas, Tak pomagam, caritas.pl/projekty/tak-pomagam [dostęp 8.12.2018]. 